\title{
Optimalisasi Hasil Bawang Merah (Allium ascalonicum, L) dengan Pupuk Organik Cair dari Daun Kelor (Moringa oleifera)
}

\author{
Mohamad Ihsan ${ }^{*}$, Srie Juli Rachmawati ${ }^{2}$, Khoirul Anwar $^{3}$, \\ dan Tri Rahayu ${ }^{4}$ \\ 1,2,3,4 Fakultas Pertanian, Program Studi Agroteknologi \\ Universitas Islam Batik Surakarta \\ JI. KH. Agus Salim No. 10. Surakarta, Jawa Tengah 57147, Telp (0271) 714751 \\ 1 Email: mohammad.xzan@gmail.com \\ *Penulis korespondensi: mohammad.xzan@gmail.com
}

Submit: $10-3-2021$

Revisi: 29-5-2021

Diterima: 5-6-2021

\begin{abstract}
This study aims to increase the yield of shallot (Allium ascalonicum, L) by adding liquid organic fertilizer from the extracted of moringa leaves and to determine the response of plants to the concentration of liquid organic fertilizer in the extract of moringa leaves. The research design used was a two-factor factorial randomized completely block design. The first factor was the moringa leaf extraction filtering technique that were: filtered with gauze, filtered with standard class 4 filter paper, and filtered with class 1 Whatman filter paper. The second factor was the concentration of organic liquid fertilizer from moringa leaf extract that were: $0 \%, 5 \%$, and $15 \%$. The data analyzed with analyze of variance (ANOVA) at the $5 \%$ and $1 \%$ significant level. The treatment of the concentration of liquid organic fertilizer affected shallot plants for the parameters: plant height, tuber weight per plant, tuber weight per plot, and weight of fresh stover. The treatment of moringa leaf extract filtering technique affected shallot plants for the observed parameters: plant height, tuber weight per plant, number of tubers per plot, and weight of fresh stover. The filtering treatment of moringa leaf extract using standard class 4 filter paper gave the best results, and the best concentration of liquid organic fertilizer for moringa leaf extraction was $5 \%$.
\end{abstract}

Keyword: Filtering, Liquid Fertilizer, Moringa Leave Extract, Organic, Shallot

\begin{abstract}
ABSTRAK
Penelitian ini bertujuan untuk meningkatkan hasil umbi bawang merah (Allium ascalonicum, L) dengan memberikan penambahan pupuk organik cair dari ekstraksi daun kelor serta untuk mengetahui respon tanaman terhadap konsentrasi pemberian pupuk organik cair ekstraksi daun kelor yang diberikan. Rancangan penelitian yang digunakan adalah Rancangan Acak Kelompok Lengkap faktorial dua faktor. Faktor pertama yaitu teknik penyaringan ekstraksi daun kelor (disaring dengan kain kasa, disaring dengan kertas saring standard kelas 4, dan disaring dengan kertas saring whatman kelas 1). Faktor kedua adalah konsentrasi pupuk cair organik dari ekstrak daun kelor $(0 \%, 5 \%, 10 \%$, dan $15 \%)$. Data dianalisis dengan sidik ragam pada jenjang nyata $5 \%$ dan $1 \%$, dan diuji lanjut menggunakan Duncan's Multiple Range Test (DMRT) pada jenjang nyata 5\%. Berdasarkan $\mathrm{F}$ hitung, perlakuan konsentrasi pemberian pupuk organik cair lebih besar dari $\mathrm{F}$ tabel $5 \%$ untuk parameter-parameter: tinggi tanaman, berat umbi per tanaman, berat umbi per petak dan berat brangkasan segar. Perlakuan teknik penyaringan ekstrak daun kelor lebih besar dari $\mathrm{F}$ tabel $5 \%$ untuk parameter-parameter pengamatan: tinggi tanaman, berat umbi per tanaman, jumlah umbi per petak, dan berat brangkasan segar. Perlakuan penyaringan ekstrak daun kelor dengan menggunakan kertas saring standard kelas 4 memberikan hasil terbaik, dan konsentrasi pemberian pupuk organik cair ekstraksi daun kelor yang terbaik adalah $5 \%$.
\end{abstract}

Kata kunci: Bawang Merah, Ekstrak Daun Kelor, Organik, Penyaringan, Pupuk Cair 


\section{Pendahuluan}

Salah satu komoditas hortikultura yang sangat strategis adalah bawang merah karena memiliki nilai ekonomis yang tinggi dan ikut mempengaruhi besarnya inflasi. Harganya sangat fluktuatif, dan permintaannya terus meningkat dari waktu ke waktu. Di tahun 2019 produksi bawang merah nasional 1,52 juta ton, dan pada tahun 2020 target produksi 1,66 juta ton. Adapun luas panen bawang merah sebesar 157.808 hektar dengan tingkat produktivitas 9,62 ton/ha (Anonim, 2020). Pemupukan yang kurang tepat di tingkat petani menjadi salah satu penyebab masih rendahnya produktivitas bawang merah. Semakin bertambahnya permintaan menyebabkan pasarnya tetap terbuka luas baik pasar dalam ataupun luar negeri, karena bawang merah banyak memiliki kegunaan bagi kehidupan manusia. Masyarakat Indonesia banyak menggunakan bawang merah sebagai salah satu jenis sayuran, terutama sebagai bumbu penyedap masakan. Semakin bertambahnya jumlah penduduk dan disertai dengan peningkatan pada daya belinya menyebabkan terjadinya peningkatan kebutuhan masyarakat terhadap bawang merah. Produksi bawang merah pada saat sekarang lebih banyak ditujukan untuk memenuhi kebutuhan dalam negeri, sehingga secara relatif ekspor bawang merah masih sangatlah sedikit. Oleh karena prospek pengembangan bawang merah masih sangat cerah, maka perlu dilakukan peningkatan produksi bawang merah baik secara nasional maupun per satuan luasnya. Untuk itu perlu dilakukan usaha-usaha baik berupa intensifikasi, ekstensifikasi maupun diversifikasi. Peningkatan produksi juga harus diimbangi dengan teknik budidaya bawang merah secara intensif yang dapat dilakukan dengan cara memaksimalkan produksi bawang merah dalam setiap satuan luasnya.

Secara agronomis upaya peningkatan produksi bawang merah dapat dicapai melalui beberapa cara yaitu pengelolaan budidaya yang mencakup pelaksanaan inovasi teknologi produksi, antara lain pemilihan varietas yang unggul, pemupukan yang tepat, penentuan jarak tanam yang optimal, pengendalian hama dan penyakit serta pengendalian gulma secara intensif. Dalam melakukan budidaya tanaman untuk mendapatkan produksi yang tinggi dengan mutu sesuai dengan yang diharapkan diperlukan penyediaan nutrisi hara bagi tanaman, selama fase pertumbuhannya. Oleh karena itu tindakan penambahan pupuk pada tanah merupakan upaya yang harus dilaksanakan karena ketersediaan unsur hara merupakan syarat utama dalam peningkatan produksi tanaman. Pemupukan bertujuan untuk menambah unsur hara bagi pencukupan kebutuhan untuk pertumbuhan dan perkembangan tanaman. Ada dua macam golongan pupuk yaitu pupuk anorganik/pupuk sintetik dan pupuk organik. Pupuk anorganik adalah kelompok pupuk fabrikan yang dibuat dengan cara mencampur berbagai macam bahan kimia sehingga pupuk yang terbuat akan mengandung unsur hara yang tinggi. Pupuk organik merupakan pupuk yang berasal dari sisa-sisa makhluk hidup yang telah mengalami proses penguraian oleh bakteri-bakteri 
perombak sehingga memiliki kandungan unsur hara dengan komposisi yang lengkap walaupun jumlah masing-masing jenis unsur haranya lebih rendah dibanding dengan pupuk anorganik. Produksi tanaman yang lestari membutuhkan penggunaan pupuk karena adanya kehilangan unsur pada kesuburan tanah. Hanya saja penggunaan pupuk kimia menyebabkan penurunan yang drastis pada kesuburan tanah di sub Sahara Afrika dan negara tropika lainnya (Awodun et al., 2007), sehingga menurunkan produktivitas tanah (Sunaryo et al., 2018).

Aplikasi pupuk organik pada lahan, selain dapat menaikkan hasil dan produktivitas tanaman, juga akan memperbaiki kemampuan tanah dalam menyimpan air, meningkatkan laju infiltrasi dan memperbaiki drainase tanah (Wahyudin et al., 2015). Menurut Wahyudin et al., (2015), pupuk kandang termasuk kelompok pupuk organik yang merupakan kotoran hewan ternak. Pupuk kandang merupakan campuran antara kotoran padat dengan sisasisa makanan serta air kencing yang berasal dari kandang ternak seperti ayam, kambing, sapi, kuda, ataupun juga burung. Beberapa manfaat yang didapatkan dari penggunaan pupuk kandang adalah: meningkatkan ketersediaan nutrisi mikro didalam tanah, menjadikan tanah lebih remah, memperbaiki sifat struktur tanah, menambah ruang pori di dalam tanah, memperbaiki aerasi, dan menyeimbangkan komposisi jasad-jasad penghuni tanah. Juga akan terjadi peningkatan daya ikat air oleh tanah, mempermudah penetrasi dan perkembangan akar tanaman, penyimpanan lengas tanah yang lebih lama, mencegah terbentuknya lapisan kerak pada tanah, menghambat tumbuhnya beberapa patogen pada akar, serta menghemat penggunaan pupuk kimia atau pupuk buatan. Semua hara makro yaitu nitrogen $(N)$, fosfor $(P)$, dan kalium $(K)$ yang berperan penting bagi pertumbuhan dan perkembangan tanaman terdapat secara lengkap di dalam pupuk kandang kambing. Kandungan unsur yang ada di dalam pupuk kandang kambing adalah: 1,19\% N; 0,92\% $\mathrm{P}_{2} \mathrm{O}_{5}$; dan 1,58\% $\mathrm{K}_{2} \mathrm{O}$ (Hikmah, 2008). Pupuk kandang kotoran kambing merupakan campuran antara kotoran padat dan cair. Kotoran dari kambing berbentuk butiran atau granul, akan pecah atau berubah menjadi remah setelah mengalami dekomposisi.

Dalam pemberian pupuk harus memperhatikan dosis yang tepat. Tidaklah mudah menentukan dosis pemupukan yang tepat. Apabila pemupukan kurang maka menyebabkan hasil yang tidak meningkat, sebab sebagai penambah unsur hara tanah pupuk organik mempunyai kelemahan yaitu kurang tersedia dan dengan kandungan hara yang lebih rendah, sehingga untuk memenuhi kebutuhan tanaman selama fase pertumbuhannya diperlukan pemberian dalam jumlah yang lebih banyak. Dosis merupakan kadar atau takaran yang diberikan. Dosis yang kurang mengakibatkan defisiensi atau kekahatan unsur hara yang dibutuhkan tanaman, sehingga pertumbuhan terhambat. Dosis yang berlebih akan memberikan pengaruh toksik atau racun, dan mengakibatkan plasmolisis pada tanaman yang berujung pada kematian (Nurrudin et al., 2020). Untuk itu 
pemberian pupuk kandang harus tepat dosis, karena pemberian pupuk organik yang berlebihan dapat memberikan pengaruh yang buruk terhadap pertumbuhan dan perkembangan tanaman, di samping juga kurang efisien. Pemberian pupuk kandang berlebihan berdampak buruk pada hasil tanaman karena pupuk kandang mengandung banyak bahan organik. Pemberian bahan organik yang berlebihan dapat menyebabkan tanah lembab, karena bahan organik mempunyai kemampuan mengikat air dalam jumlah yang tinggi. Sebaliknya, pemberian pupuk kandang yang kurang (dengan dosis rendah) dapat menghambat pertumbuhan tanaman, karena tanaman tersebut kekurangan unsur hara. Pupuk dapat juga diberikan lewat daun. Beberapa keunggulan pemberian pupuk melalui daun yaitu: masuknya larutan yang membawa nutrisi ke dalam stomata daun menjadikannya lebih cepat terserap oleh tanaman sehingga hasilnya akan lebih cepat nampak yaitu dengan kemunculan tunas-tunas baru. Keuntungan lainnya pada pemupukan lewat daun: terhindarnya kejadian adanya kompetisi antar unsur pada proses pertukaran kation antara permukaan koloid tanah dengan permukaan akar di dalam tanah, mengurangi kehilangan unsur melalui pencucian oleh air infiltrasi (leaching) dan penyematan (fixation) oleh permukaan koloid lempung atau oleh bahan-bahan lain. Pemupukan lewat daun tidak boleh menjadi satu-satunya cara pemasokan hara untuk tanaman sehingga pemberian hara melalui tanah diabaikan, karena pemupukan lewat daun hanyalah upaya untuk melengkapi ketersediaan unsur hara bagi tanaman. Masuknya unsur hara ke dalam tanaman melalui stomata daun terjadi karena adanya proses difusi dan osmosis. Pupuk organik cair dibuat dari ekstraksi atau hasil fermentasi bahan-bahan organik yang diambil larutannya. Pupuk organik cair yang diperoleh dari ekstraksi daun tanaman merupakan salah satu dari jenis pupuk cair organik yang memiliki potensi besar untuk digunakan. Hal ini karena di dalam daun tanaman terdapat unsur hara yang lengkap hasil dari proses metabolisme dalam tubuh tanaman tersebut

Tanaman kelor (Moringa oleifera, Lam) berasal dari India, banyak tumbuh di daerah yang beriklim tropika dan subtropika di seluruh dunia. Tanaman ini biasa disebut sebagai "drumstick tree" atau juga "horseradish tree" (pohon lobak) (Gopalakrishnan et al., 2016). Orang Eropa menyebut tanaman ini sebagai the miracle tree. Sebutan lain dari tanaman ini adalah ben-tree, benzolive tree, cabbage tree, kelor tree, moringa, radish tree, dan west indian ben. Di Indonesia dikenal sebagai: kero, wori, ke lo atau kelor o (Sulawesi); maronggih (Madura); kelor (Sunda dan Melayu) (Rochmawati et al., 2015). Didalam daun kelor banyak terkandung vitamin A, B, C, mineral, antioksidan, juga asam amino esensial sehingga diduga paling tidak terdapat sekitar 300 macam penyakit yang dapat disembuhkan dengan mengonsumsi atau menggunakan makanan olahan dengan bahan dasar tanaman ini (Sugianto, 2016). Dikatakan pula bahwa sebagai sumber gizi alami, kelor merupakan kelompok tanaman pangan yang penting karena dari daun, buah, bunga 
dan polongnya yang belum matang, dapat digunakan sebagai sayuran bernutrisi tinggi. Menurut Aminah et al., (2015), didalam daun kelor terkandung: 28,44\% protein; 57,01\% karbohidrat; 2,74\% lemak; 7,95\% abu, dan sisanya berupa serat. Kelor kaya akan nutrisi karena keberadaan bermacam-macam zat fotokimia yang terkandung di dalam daun, polong, dan bijinya. Dikatakan pula bahwa di dalam daun kelor terkandung vitamin $\mathrm{C}$ sejumlah 7 kali lipat dibanding dengan jeruk, vitamin A dengan jumlah 10 kali lipat dibanding wortel, kalsium dengan jumlah 17 kali lipat daripada susu, protein 9 kali lipat dibanding yoghurt, kalium 15 kali lipat dibanding pisang, dan mengandung besi 25 kali lipat daripada bayam (Gopalakrishnan et al., 2016). Zat-zat fotokimia utama yang dapat diperoleh dari tanaman ini meliputi: tannin, saponin, alkaloid, flavonoid, fenol, dan glikosida dari daunnya (Mensah et al., 2012); tannin, steroid, flavonoid, alkaloid, glykosida, quersetin, dan terpenoid dari bunganya. Senyawa-senyawa tersebut mempunyai kemampuan sebagai obat antibiotik, anti-inflamasi yang lebih manjur daripada madu dan kunyit (Anonim, 2018), detoksifikasi dan antibakteri. Lebih dari itu, kelor juga digunakan secara luas untuk perbaikan kualitas air dari kemampuan sifat kelor untuk mengkoagulasi, flokulasi dan sedimentasi sehingga dapat menurunkan kandungan bahan organik dan populasi mikroorganisme bagi kebutuhan akua kultur (Brilhante et al., 2017). Penggunaan biji kelor sebagai biokoagulan untuk mengurangi kadar logam dalam air, juga didasarkan pada hasil penelitian sebelumnya, antara lain: serbuk biji kelor dapat menurunkan kadar timbal, kekeruhan dan intensitas warnanya (Nugroho et al., 2014). Biji kelor terbukti dapat digunakan sebagai koagulan dalam menurunkan kadar ion logam cadmium (II) (Akbar et al., 2015). Biji kelor dapat sebagai pengikat fosfat untuk membentuk koagulasi dalam limbah cair rumah sakit. Biji kelor juga dapat digunakan sebagai koagulan dalam menurunkan kekeruhan, kadar ion besi dan mangan dalam air (Srawaili, 2007). Dari analisis menggunakan AAS (Atomic Absorption Spectophotometry) diperoleh hasil secara rata-rata terdapat $0,505 \%$ kadar kalsium pada daun kelor (Abrianti et al., 2018). Juga diperoleh hasil bahwa dengan metode konduktometri didalam intraseluler kelor terdapat kalium sebanyak 625,6 mg/100 g, sedangkan dengan metode AAS diperoleh hasil kandungan kaliumnya 1001,28 mg/100g (Rochmawati et al., 2015). Didalam daun kelor juga terkandung sitokinin dan zeatin (Rahman et al., 2017), bahkan menurut Culver et al., (2012) kandungan zeatinnya berkisar 5-200 $\mu \mathrm{g} / \mathrm{g}$ daun.

Pada saat ini budidaya tanaman kelor telah banyak dilakukan oleh masyarakat. Tanaman ini dapat tumbuh pada wilayah tropika dan subtropika pada suhu antara $25-35^{\circ} \mathrm{C}$. Tanah yang diperlukan bertekstur pasiran atau geluhan dengan reaksi tanah dari asam lemah sampai basa lemah, curah hujan antara 250-3000 mm/bulan. Oleh karena tanaman kelor dapat tumbuh dengan cepat, maka ada saatnya banyak bagian tanaman yang pada akhirnya tidak termanfaatkan secara optimal. Produksi biomassa tanaman kelor ini sebenarnya dapat 
dimanfatkan sebagai pupuk cair organik selain juga sebagai pupuk hijau. Pupuk yang disemprotkan ke bagian bawah daun tempat terdapatnya banyak stomata, akan mengalami penyerapan karena adanya proses diffusi dan osmosis. Karena itulah pemberiannya harus dengan konsentrasi yang tepat agar unsur hara yang terdapat dalam pupuk tersebut secara keseluruhan dapat terserap dan mengurangi resiko terjadinya efek samping seperti peristiwa plasmolisis ataupun yang lain. Ekstrak yang berasal daun kelor juga dapat dipakai sebagai hormon tumbuh yang mempengaruhi daya tumbuh pada pembibitan tanaman tebu. (Rahman et al., 2017) dalam percobaannya mendapatkan hasil bahwa terdapat pengaruh ekstrak daun kelor terhadap volume akar bibit tebu yang terbentuk. Beberapa peneliti lain mendapatkan hasil bahwa ekstraksi daun kelor terbukti bermanfaat sebagai pupuk cair (Krisnadi, 2015), karena dapat meningkatkan diameter batang, jumlah akar, jumlah tunas, dan jumlah buah pada tanaman tomat (Culver et al., 2012).

\section{$2 \quad$ Metode Penelitian}

Pada penelitian ini digunakan Rancangan Acak Kelompok Lengkap (RAKL) sebagai rancangan lingkungannya, dengan tiga buah blok sebagai ulangan. Terdapat dua macam faktor perlakuan yang dicobakan ialah faktor konsentrasi Pupuk Organik Cair (POC) ekstrak daun kelor dan faktor model penyaringan ekstrak dalam proses ekstraksinya. Faktor perlakuan pemberian konsentrasi POC (C) memiliki 4 tingkat yaitu: (1) Pemberian POC 0\% $\left(C_{0}\right)$; (2) Pemberian POC 5\% $\left(C_{1}\right)$; (3) Pemberian POC 10\% $\left(C_{2}\right)$; dan (4) Pemberian POC $15 \%\left(C_{3}\right)$. Faktor perlakuan teknik penyaringan ekstrak $(T)$, terdiri atas 3 macam yaitu: $(1)$ disaring dengan kain kasa ( $\left.T_{1}\right)$; (2) disaring dengan kertas saring biasa standard $4\left(T_{2}\right)$; dan (3) disaring dengan kertas saring whatman $\left(\mathrm{T}_{3}\right)$. Petak tanah setelah diolah selanjutnya dihamparkan pupuk kandang kotoran kambing dengan takaran 20 ton ha-1. Penyemprotan menggunakan pupuk cair ekstrak daun kelor dilakukan mulai tanaman berumur 15 hari, dengan interval waktu 5 hari dan dilakukan sampai tanaman berumur 50 hari.

\section{Bahan}

Bahan-bahan penelitian: benih bawang merah, pupuk kandang kambing, daun kelor.

\section{Pembuatan Pupuk Organik Cair.}

1. Daun kelor sebanyak $1 \mathrm{~kg}$ dihaluskan dengan menggunakan blender, kemudian dilarutkan dalam 3 liter air aquades. Selanjutnya dibagi menjadi 3 bagian, diperlakukan dengan tiga (3) macam metode penyaringan yaitu: disaring menggunakan kain kasa, disaring menggunakan kertas saring standard 4, dan disaring menggunakan kertas saring Whatman. 
2. Semua larutan hasil penyaringan kemudian difermentasikan pada botol yang dibuka tutupnya dengan menambahkan larutan ragi masing-masing $10 \mathrm{ml}$ dan diinkubasikan selama 1 bulan.

3. Setelah 1 bulan, larutan siap untuk digunakan.

\section{Variabel Pengamatan dan Analisis Data}

Bagian tanaman yang diamati meliputi: tinggi, berat brangkasan segar, berat umbi per tanaman, berat umbi per petak, dan jumlah umbi. Selanjutnya data yang diperoleh diolah dengan menggunakan uji varian (Uji F) pada tingkat kepercayaan 5\% dan 1\%. Pengujian lanjutan terhadap rata-rata hasil perlakuan dari perlakuan yang berbeda nyata dilakukan dengan menggunakan uji jarak berganda Duncan's (DMRT) pada tingkat kepercayaan $5 \%$.

\section{Hasil dan Pembahasan}

Tabel 1. Pengaruh konsentrasi pemberian POC dan teknik penyaringan ekstraksi daun kelor terhadap beberapa variabel pertumbuhan tanaman bawang merah

\begin{tabular}{|c|c|c|c|c|c|}
\hline \multirow[b]{2}{*}{$\begin{array}{l}\text { Variabel } \\
\text { tanaman }\end{array}$} & \multirow[b]{2}{*}{$\begin{array}{c}\text { Konsentrasi } \\
\text { POC }\end{array}$} & \multicolumn{3}{|c|}{ Teknik Penyaringan } & \multirow[b]{2}{*}{ Rata-rata } \\
\hline & & $\begin{array}{c}\text { Disaring } \\
\text { dengan kain }\end{array}$ & $\begin{array}{c}\text { Disaring } \\
\text { dengan kertas } \\
\text { saring } \\
\text { standard }\end{array}$ & $\begin{array}{c}\text { Disaring } \\
\text { dengan kertas } \\
\text { saring } \\
\text { whatman }\end{array}$ & \\
\hline \multirow{5}{*}{$\begin{array}{c}\text { Tinggi } \\
\text { tanaman }(\mathrm{cm})\end{array}$} & POC 0\% & $34,77 \mathrm{~d}$ & $36,10 \mathrm{~d}$ & $31,30 \mathrm{e}$ & $34,06 \mathrm{c}$ \\
\hline & POC $5 \%$ & $37,53 \mathrm{bc}$ & $41,47 \mathrm{a}$ & $37,67 \mathrm{~b}$ & $38,89 \mathrm{a}$ \\
\hline & POC $10 \%$ & $37,80 \mathrm{~b}$ & $37,90 \mathrm{~b}$ & $37,87 \mathrm{~b}$ & 37,86 b \\
\hline & POC 15\% & $37,93 \mathrm{~b}$ & $38,77 \mathrm{~b}$ & $37,87 \mathrm{~b}$ & $38,19 \mathrm{~b}$ \\
\hline & Rata-rata & $37,01 \mathrm{~b}$ & 38,56 a & $36,18 \mathrm{c}$ & \\
\hline \multirow{5}{*}{$\begin{array}{c}\text { Berat } \\
\text { brangkasan } \\
\text { segar }(g)\end{array}$} & POC 0\% & 38,93 & 44,60 & 31,21 & $38,35 \mathrm{c}$ \\
\hline & POC $5 \%$ & 45,74 & 75,60 & 37,24 & $52,86 \mathrm{~b}$ \\
\hline & POC $10 \%$ & 37,99 & 46,88 & 38,56 & $41,14 \mathrm{c}$ \\
\hline & POC $15 \%$ & 61,61 & 61,74 & 61,23 & $61,86 \mathrm{a}$ \\
\hline & Rata-rata & $46,07 \mathrm{~b}$ & $57,45 \mathrm{a}$ & $42,06 \mathrm{c}$ & \\
\hline
\end{tabular}

Keterangan: Rata-rata perlakuan yang diikuti oleh huruf yang sama pada kolom atau baris yang sama menunjukkan tidak berbeda nyata pada uji Duncan 5\% POC = Pupuk Organik Cair ekstrak daun kelor

Pada peubah tinggi tanaman bawang merah, hasil tertinggi diperoleh pada kombinasi perlakuan pemberian POC 5\% yang disaring dengan kertas saring standard, sedangkan yang paling rendah terdapat pada perlakuan dengan kombinasi pemberian POC $0 \%$ yang disaring dengan kertas saring Whatman. Hasil ini menunjukkan bahwa perlakuan penyaringan ekstrak daun kelor dengan menggunakan kertas saring standard menjadikan tinggi tanaman lebih tinggi daripada tanaman yang disemprot dengan ekstrak daun kelor yang disaring dengan teknik penyaringan yang lain, sehingga juga akan tumbuh lebih baik. Perlakuan macam teknik penyaringan, takaran konsentrasi pemberian pupuk cair, serta interaksi antara kedua macam perlakuan itu memberikan beda nyata terhadap peubah ini. Ini menunjukkan bahwa kedua macam perlakuan yang dicobakan menyebabkan peningkatan pertumbuhan tanaman bawang merah secara berbeda. Ketiga macam teknik penyaringan ekstrak daun kelor yang dicobakan memiliki sifat dan efektivitas 
pengaruh yang tidak sama. Terdapatnya perbedaan kandungan hara dalam masingmasing konsentrasi pupuk cair yang diberikan akan menjadikan adanya perbedaan pada pertumbuhan tanaman yang diamati utamanya pada peubah tinggi tanaman. Hasil Uji jarak berganda Duncan untuk membandingkan antar rata-rata tinggi tanaman bawang merah yang diperlakukan dengan beberapa macam teknik penyaringan ekstrak daun kelor dan konsentrasi pemberiannya, menunjukkan hasil bahwa teknik penyaringan dengan menggunakan kertas saring standard memberikan pengaruh paling baik dibanding yang disaring dengan kain ataupun dengan kertas Whatman. Asumsi umum bahwa pemberian konsentrasi pupuk cair yang semakin tinggi sampai batas-batas tertentu, akan menjadikan pertumbuhan tanaman yang semakin baik. Pada percobaan ini ternyata asumsi di atas tidak sepenuhnya Nampak, utamanya pada parameter tinggi tanaman bawang merah. Hal ini mengindikasikan bahwa pada pemberian pupuk cair ekstrak daun kelor dengan takaran paling rendah sebenarnya sudah memenuhi kebutuhan minimun bagi pertumbuhan tanaman bawang merah, sehingga apabila takaran pemberiannya ditingkatkan pertumbuhan tanaman tidak akan semakin bagus pula.

Perlakuan teknik penyaringan dan konsentrasi pemberian POC memberikan beda nyata pada berat brangkasan segar tanaman bawang merah, tetapi tidak ada interaksi antara kedua macam perlakuan yang dicobakan. Berat brangkasan segar tanaman bawang merah tertinggi terdapat pada kombinasi perlakuan pemberian pupuk cair dengan konsentrasi $5 \%$ dan penyaringan dengan kertas saring biasa, sedangkan berat terendahnya ada pada kombinasi perlakuan pemberian pupuk cair dengan konsentrasi $0 \%$ dan penyaringan dengan kertas saring Whatman. Tampak jelas bahwa perlakuan penyaringan dengan kertas saring standard menjadikan tanaman bawang merah tumbuh lebih baik dibanding perlakuan dengan teknik penyaringan yang lain. Pada penyaringan dengan kertas saring standard, partikel-partikel yang lolos berupa senyawa-senyawa sederhana hasil perombakan bahan organik ekstrak daun kelor yang dapat digunakan dalam proses fisiologis tanaman. Penyaringan dengan menggunakan kain akan lebih banyak meloloskan partikel-partikel kasar, sedangkan penyaringan dengan menggunakan kertas saring whatman selain lebih lama juga diduga menyebabkan banyak senyawasenyawa yang tertinggal di permukaan kertas saring. Partikel-partikel kasar yang lolos dari saringan kain akan menjadi penghambat (barrier) pada mulut stomata sehingga hanya sedikit hara yang masuk ke dalamnya. Karena itulah pada akhirnya berat brangkasan tanaman lebih rendah daripada yang diperlakukan dengan teknik penyaringan menggunakan kertas saring biasa. Unsur hara yang terkandung di dalam filtrat hasil filtrasi dengan kertas saring whatman lebih sedikit daripada dari yang disaring menggunakan kain, terlebih lagi jika dibandingkan dengan yang disaring menggunakan kertas saring biasa. Terdapat juga unsur mikro dari hasil perombakan ekstrak daun kelor. Unsur hara mikro 
yang mencakup unsur boron $(B)$, seng $(Z n)$ dan besi $(F e)$ juga berpengaruh terhadap peubah berat brangkasan tanaman oleh karena unsur B berperan untuk terbentuknya sel, unsur Zn dan Fe memiliki fungsi pada saat proses pembentukan klorofil. Data ini identik dengan yang diperoleh pada penelitian dengan perlakuan yang sama dengan komoditas yang berbeda yaitu terhadap tanaman sawi utamanya pada parameter pengamatan berat segar tanaman sawi (Ihsan et al., 2020).

Tabel 2. Pengaruh konsentrasi pemberian $P O C$ dan teknik penyaringan ekstraksi daun kelor terhadap beberapa variabel hasil tanaman bawang merah

\begin{tabular}{|c|c|c|c|c|c|}
\hline \multirow[b]{2}{*}{$\begin{array}{l}\text { Variabel } \\
\text { tanaman }\end{array}$} & \multirow[b]{2}{*}{$\begin{array}{l}\text { Konsentrasi } \\
\text { POC }\end{array}$} & \multicolumn{3}{|c|}{ Teknik Penyaringan } & \multirow[b]{2}{*}{ Rata-rata } \\
\hline & & $\begin{array}{c}\text { Disaring } \\
\text { dengan kain }\end{array}$ & $\begin{array}{l}\text { Disaring } \\
\text { dengan } \\
\text { kertas saring } \\
\text { standard }\end{array}$ & $\begin{array}{c}\text { Disaring } \\
\text { dengan } \\
\text { kertas saring } \\
\text { whatman }\end{array}$ & \\
\hline \multirow{5}{*}{$\begin{array}{l}\text { Berat umbi per } \\
\text { tanaman } \\
\text { (g) }\end{array}$} & POC 0\% & $94,67 \mathrm{f}$ & 111,89 cde & $91,67 \mathrm{f}$ & $99,21 \mathrm{c}$ \\
\hline & POC 5\% & 113,21 bcde & $159,14 \mathrm{a}$ & 96,95 ef & $123,10 \mathrm{a}$ \\
\hline & POC $10 \%$ & 106,78 def & $123,98 \mathrm{bc}$ & 104,14 def & $111,63 \mathrm{~b}$ \\
\hline & POC $15 \%$ & $123,61 \mathrm{bc}$ & $115,48 \mathrm{bcd}$ & $127,39 \mathrm{~b}$ & $122,16 \mathrm{a}$ \\
\hline & Rata-rata & $109,57 \mathrm{~b}$ & $127,62 \mathrm{a}$ & $105,04 \mathrm{c}$ & \\
\hline \multirow{5}{*}{$\begin{array}{l}\text { Berat umbi per } \\
\text { petak } \\
\text { (g) }\end{array}$} & POC 0\% & $1828,58 \mathrm{e}$ & $2020,41 \mathrm{cde}$ & $1923,08 \mathrm{de}$ & $1924,02 \mathrm{~d}$ \\
\hline & POC 5\% & $2224,53 \mathrm{c}$ & 2962,58 a & $2108,30 \mathrm{~cd}$ & $2431,80 \mathrm{a}$ \\
\hline & POC $10 \%$ & $2167,83 \mathrm{~cd}$ & 1989,23 cde & $2230,20 \mathrm{c}$ & $2129,09 \mathrm{c}$ \\
\hline & POC $15 \%$ & $2494,80 \mathrm{~b}$ & $2205,63 \mathrm{c}$ & $2149,88 \mathrm{~cd}$ & $2283,44 \mathrm{~b}$ \\
\hline & Rata-rata & $2178,94 \mathrm{~b}$ & $2294,46 \mathrm{a}$ & $2102,86 \mathrm{c}$ & \\
\hline \multirow{5}{*}{$\begin{array}{l}\text { Jumlah umbi } \\
\text { per petak }\end{array}$} & POC 0\% & 230,33 & 198,67 & 223,33 & $217,44 \mathrm{c}$ \\
\hline & POC 5\% & 231,00 & 318,33 & 250,67 & $266,67 \mathrm{a}$ \\
\hline & POC 10\% & 226,67 & 231,00 & 247,00 & $234,89 \mathrm{~b}$ \\
\hline & POC $15 \%$ & 245,33 & 233,33 & 235,67 & $238,11 b$ \\
\hline & & $233,33 \mathrm{a}$ & 245,33 a & $239,17 \mathrm{a}$ & \\
\hline
\end{tabular}

Keterangan: Rata-rata perlakuan yang diikuti oleh huruf yang sama pada kolom atau baris yang sama menunjukkan tidak berbeda nyata pada uji Duncan 5\% $\mathrm{POC}=$ Pupuk Organik Cair ekstrak dari daun kelor

Pada peubah berat umbi per tanaman bawang merah, angka tertinggi terdapat pada kombinasi pemberian POC 5\% yang disaring dengan kertas saring standard, sedangkan yang terkecil ada pada kombinasi perlakuan pemberian POC $0 \%$ yang disaring dengan kertas saring Whatman. Hasil ini menunjukkan bahwa perlakuan penyaringan dengan kertas saring standard memberikan berat umbi tanaman bawang merah yang lebih baik daripada berat umbi pada tanaman yang diberi ekstrak daun kelor dari penyaringan dengan teknik yang lain. Secara umum kecukupan hara didalam rhizosfer akan mendorong pertumbuhan tanaman karena terjadinya penambahan jumlah dan ukuran sel tanaman, yang tentunya berimbas kepada pengisian cadangan makanannya. Tanaman bawang merah membutuhkan nutrisi makro dalam jumlah yang banyak agar dapat tumbuh optimum dan dapat menyimpan makanan dalam jumlah besar ke dalam umbinya, sehingga pemupukan melalui tanah merupakan cara yang tepat untuk memenuhi kebutuhan tanaman. Pemberian pupuk melalui daun juga akan semakin menambah ketersediaan hara bagi pembentukan sel tanaman. Sel-sel yang terbentuk akan memperbanyak dan menambah besar ukuran organ-organ tanaman termasuk juga daun. Umbi lapis bawang merah terbentuk oleh proses pembesaran pada lapisan-lapisan daun yang selanjutnya 
berkembang dan tumbuh menjadi umbi lapis. Didalam daun kelor kaya dengan unsur kalium (K) dan kalsium (Ca). Kalium berperan dalam mengatur proses fisiologis tanaman yang mencakup fotosintesis, akumulasi, translokasi dan transportasi karbohidrat, membuka dan menutupnya stomata, juga ikut mengatur pendistribusian air dalam sel dan jaringan. Kecukupan hara kalsium bagi tanaman akan mengoptimalkan laju fotosintesis dimana reaksi inilah yang menstimulir pembentukan umbi menjadi lebih besar sehingga dapat meningkatkan berat tanaman karena hasil fotosintesis akan lebih banyak didistribusikan dalam pengisian umbi (Fatirahma \& Kastono, 2020). Dari hasil analisis keragaman didapatkan fakta bahwa kedua macam perlakuan yang dicobakan yaitu perlakuan macam model penyaringan dan perlakuan konsentrasi pemberiannya serta interaksi antara kedua macam perlakuan tersebut memberikan perbedaan yang nyata. Hasil berat umbi per petak tanaman bawang merah paling tinggi didapatkan pada kombinasi perlakuan pemberian POC 5\% yang disaring dengan kertas saring biasa. Hasil ini menunjukkan bahwa perlakuan penyaringan ekstrak daun kelor menggunakan kertas saring biasa memberikan hasil berupa berat umbi per petak tanaman bawang merah yang lebih baik dibandingkan dengan penyaringan dengan yang lain. Dari pengolahan data juga didapatkan hasil bahwa perlakuan model penyaringan tidak memberikan beda nyata, sedangkan perlakuan konsentrasi pemberian dan interaksi antara kedua macam perlakuan memberikan beda nyata pada peubah berat umbi per petak.

Data pada tabel 2 memperlihatkan pemberian pupuk cair ekstrak daun kelor yang disaring dengan kertas saring biasa pada takaran paling rendah sudah mencukupi kebutuhan minimum tanaman bawang merah yang dicobakan, sehingga jikapun konsentrasi pemberiannya ditingkatkan hasil tanaman tidak akan semakin baik. Jumlah umbi bawang merah per petak tertinggi didapatkan dari kombinasi perlakuan aplikasi pupuk cair organik ekstrak daun kelor dengan konsentrasi 5\% dan penyaringan dengan kertas saring biasa. Hasil ini menunjukkan bahwa perlakuan penyaringan dengan kertas saring biasa memberikan jumlah umbi bawang merah per petak yang secara rata-rata lebih banyak dibandingkan dengan penyaringan yang lain.

Dengan menggunakan uji $\mathrm{F}$ terhadap data yang diperoleh, didapatkan hasil hanya perlakuan konsentrasi pemberian pupuk cair yang memberikan beda nyata. Artinya pada setiap aras perlakuan konsentrasi pupuk cair yang dicobakan mendorong penambahan pertumbuhan tanaman secara tidak sama. Hasil percobaan yang diperoleh ini mengindikasikan bahwa pada pemberian konsentrasi pupuk cair ekstrak daun kelor yang paling kecil sebenarnya sudah mencukupi kebutuhan minimum untuk pertumbuhan tanaman bawang merah, sehingga apabila konsentrasi pemberiannya ditingkatkan pertumbuhan tanaman yang didapatkan tidak selaras peningkatan pemberian unsur tersebut. 




Gambar 1. Pengaruh teknik penyaringan dan konsentrasi pupuk organik cair ekstraksi daun kelor terhadap rata-rata jumlah umbi bawang merah per tanaman

Pada Gambar 1 ditampilkan data tentang jumlah umbi bawang merah setiap tanaman dimana hasil tertinggi terdapat pada kombinasi pemberian pupuk cair dengan konsentrasi $5 \%$ dan penyaringan dengan kertas saring biasa, sedangkan tinggi terkecil terdapat pada kombinasi perlakuan pemberian pupuk cair dengan konsentrasi $0 \%$ dan penyaringan dengan kertas saring Whatman. Hasil ini identik dengan yang didapatkan oleh Uke et al., (2015) yang melakukan penelitian pada bawang merah dengan perlakuan pemberian pupuk kalium dimana pada pemberian kalium dengan takaran terendah (150 kg ha $^{-1}$ ) memberikan jumlah umbi yang tertinggi. Pengujian dengan uji $\mathrm{F}$ memberikan hasil bahwa perlakuan macam model penyaringan dan konsentrasi pemberian pupuk organik cair tidak memberikan beda nyata terhadap peubah jumlah umbi per tanaman. Ini menunjukkan bahwa kedua macam perlakuan yang dicobakan tidak secara nyata memberikan peningkatan pertumbuhan tanaman terutama pada peubah jumlah umbi per tanaman bawang merah. Kedua macam perlakuan yang diujikan memberikan peningkatan pertumbuhan tanaman secara tidak sama pada masing-masing arasnya.

\section{$4 \quad$ Kesimpulan}

Perlakuan konsentrasi pemberian pupuk organik cair ekstrak daun kelor berpengaruh pada tanaman bawang merah untuk parameter-parameter: tinggi tanaman, berat umbi per tanaman, berat umbi per petak dan berat brangkasan segar. Perlakuan model penyaringan ekstrak daun kelor berpengaruh pada tanaman bawang merah untuk 
parameter-parameter pengamatan: tinggi tanaman, berat umbi per tanaman, jumlah umbi per petak, dan berat brangkasan segar. Perlakuan penyaringan ekstrak daun kelor dengan menggunakan kertas saring standard kelas 4 memberikan hasil terbaik, dengan konsentrasi pemberian pupuk organik cair ekstraksi daun kelor yang terbaik adalah $5 \%$.

\section{Daftar Pustaka}

Abrianti, R. N. W., Sayekti, S., \& Prasetyaningati, D. (2018). Gambaran Kadar Kalsium Pada Daun Kelor (Moringa oleifera Lam.) dan Susu Sapi Segar Menggunakan Metode AAS (Atomic Absorption Spektrophotometry). STIKES INSAN CENDEKIA MEDIKA JOMBANG.

Akbar, A., Said, I., \& Diah, A. (2015). Efektifitas Biji Kelor (Moringa Oleifera Lamk) sebagai Koagulan Besi (Fe) dan Kalsium (Ca). Jurnal Akademika Kimia, 4(2), 64-70.

Aminah, S., Ramdhan, T., \& Yanis, M. (2015). Kandungan nutrisi dan sifat fungsional tanaman kelor (Moringa oleifera). Buletin Pertanian Perkotaan, 5(2), 35-44.

Anonim. (2018). Tanaman Kelor Kerap Disebut "Pohon Ajaib", Ini Sederet Manfaat Tanaman dan Daun Kelor. Retrieved April 24, 2019, from https://jogja.tribunnews.com/2018/11/15/tanaman-kelor-kerap-disebut-pohon-ajaibini-sederet-manfaat-tanaman-dan-daun-kelor?page=all

Anonim. (2020). Kementan Targetkan Produksi Bawang Merah-Cabai Naik 7 Persen. Retrieved from https://www.cnnindonesia.com/ekonomi/20200211141353-92473592/kementan-targetkan-produksi-bawang-merah-cabai-naik-7-persen

Awodun, M. A., Omonijo, L. I., \& Ojeniyi, S. O. (2007). Effect of goat dung and NPK fertilizer on soil and leaf nutrient content, growth and yield of pepper. International Journal of Soil Science, 2(2), 142-147.

Brilhante, R. S. N., Sales, J. A., Pereira, V. S., Castelo-Branco, D. de S. C. M., Cordeiro, R. de A., de Souza Sampaio, C. M., de Araújo Neto Paiva, M., Santos, J. B. F. dos., Sidrim, J. J. C. \& Rocha, M. F. G. (2017). Research advances on the multiple uses of Moringa oleifera: A sustainable alternative for socially neglected population. Asian Pacific Journal of Tropical Medicine, 10(7), 621-630. https://doi.org/https://doi.org/10.1016/j.apjtm.2017.07.002

Culver, M., Fanuel, T., \& Chiteka, A. Z. (2012). Effect of Moringa Extract on Growth and Yield of Tomato. Greener Journal of Agricultural Sciences, 2(5), 207-211.

Fatirahma, F., \& Kastono, D. (2020). Pengaruh Pupuk Organik Cair terhadap Hasil Bawang Merah ( Allium cepa L . Aggregatum group ) di Lahan Pasir. Jurnal Vegetalika, 9(1), 305-315. https://doi.org/10.22146/veg.47792

Gopalakrishnan, L., Doriya, K., \& Kumar, D. S. (2016). Moringa oleifera: A review on nutritive importance and its medicinal application. Food Science and Human Wellness, 5(2), 49-56. https://doi.org/https://doi.org/10.1016/j.fshw.2016.04.001

Ihsan, M., Rachmawati, S. J., \& Styadi, I. (2020). Metode Penyaringan Ekstrak Daun Kelor (Moringa oleifera) sebagai Pupuk Organik Cair bagi Pertumbuhan dan Hasil Tanaman Sawi (Brassica juncea, L). Daun: Jurnal IImiah Pertanian Dan Kehutanan, 7(2), 126137. 
Krisnadi, A. D. (2015). Kelor Super Nutrisi Edisi Revisi. In Pusat Informasi dan Pengembangan Tanaman Kelor Indonesia. Lembaga Swadaya Masyarakat-Media Peduli Lingkungan (LSM-MEPELING). Blora.

Mensah, J. K., Ikhajiagbe, B., Edema, N. E., \& Emokhor, J. (2012). Phytochemical, nutritional and antibacterial properties of dried leaf powder of Moringa oleifera (Lam) from Edo Central Province, Nigeria. J. Nat. Prod. Plant Resour., 2(1), 107-112.

Nugroho, B. A., Miswadi, S. S., \& Santosa, N. B. (2014). Penggunaan Serbuk Biji Kelor Untuk Menurunkan Kadar $\mathrm{Pb}$, Kekeruhan dan Intensitas Warna. Indonesian Journal of Chemical Science, 3(3).

Nurrudin, A., Haryono, G., \& Susilowati, Y. E. (2020). Pengaruh Dosis Pupuk N dan Pupuk Kandang Ayam Terhadap Hasil Tanaman Kubis (Brassica oleracea, L) Var. Grand 11. Vigor: Jurnal IImu Pertanian Tropika dan Subtropika, 5(1), 1-6. https://doi.org/10.31002/vigor.v5i1.2411

Rahman, M., Karno, \& Kristanto, B. A. (2017). Pemanfaatan Tanaman Kelor (Moringa oleifera) sebagai Hormon Tumbuh pada Pembibitan Tanaman Tebu (Saccharum officinarum, L). J. Agro Complex, 1(3), 94-100.

Rochmawati, A., Effendi, D., \& Hamdani, S. (2015). Pengembangan Metode Analisis Kadar Kalium dalam Daun Kelor (Moringa Oleifera) dengan Metode Konduktometri. Prosiding Penelitian SPeSIA Unisba, 591-595.

Srawaili, N. (2007). A Caladium Seed (Moringa oleifera) Bio coagulant Effectivity to Decrease Ferum ( $\mathrm{Fe}$ ) and Manganese $(\mathrm{Mn})$ Concentration from Aqueous Solution. Journal Environmental Science, 57(4), 3549-3556.

Sugianto, A. K. (2016). Kandungan Gizi Daun Kelor (Moringa oleifera) Berdasarkan Posisi Daun dan Suhu Penyeduhan. Bogor: Dep. Gizi Masyarakat Fak. Ekologi Manusia, IPB.

Sunaryo, Y., Purnomo, D., Darini, M. T., \& Cahyani, V. R. (2018). Nutrients content and quality of liquid fertilizer made from goat manure. Journal of Physics: Conference Series, 1022(1). https://doi.org/10.1088/1742-6596/1022/1/012053

Uke, K. H. Y., Barus, H., \& Madauna, I. S. (2015). Pengaruh Ukuran Umbi dan Dosis Kalium Terhadap Pertumbuhan dan Hasil Produksi Bawang Merah (Allium ascalonicum L.) Varietas Lembah Palu. Agrotekbis, 3(6), 655-661. https://doi.org/10.24198/kultivasi.v14i2.12041

Wahyudin, A., Nurmala, T., \& Rahmawati, R. D. (2015). Pengaruh Dosis Pupuk Fosfor dan Pupuk Organik Cair Terhadap Pertumbuhan dan Hasil Kacang Hijau (Vigna radiata L.) Pada Ultisol Jatinangor. Kultivasi, 14(2), 16-22. https://doi.org/10.24198/kultivasi.v14i2.12041 